\title{
Physiotherapy in the surgical treatment of Chagasic Megaesophagus
}

Daniella Alves Vento ${ }^{1}$, Isabella Ribeiro Araújo ${ }^{1}$, Luiz Fernando Martins de Souza Filho ${ }^{1}$, Michael Taylor Oliveira²,

1. Federal University of Goiás (ESEFFEGO), Natal-RN, Brazil.

2. University Center UniEvangélica, Anápolis-GO- Brazil

Study performed at clinical Hospital of Federal University of Goiás

Financial support: None.

Conflict of interest: None.

Correspondence address: Daniella Alves Vento, Endereço: Rua T-27, 300, setor Bueno, GoiâniaGO-Brazil. Zip Code: 74210-30, Email: daniellaavento@hotmail.com

Submitted: april 8; accepted after revision, April 22, 2019.

\section{ABSTRACT}

Introduction: Chagasic Megaesophagus (CME) is the manifestation of the disease characterized by luminal enlargement and muscular hypertrophy. Physiotherapy is an area that can be beneficial to CME patients in both pre and postoperative stages due to evidence of its success rate in preventing pulmonary complications. Objective: analyze the use of physiotherapeutic treatment in treating patients that underwent surgical treatment for CME. Methods: Study developed at University Federal of Goiás- Hospital das Clínicas, in Goiânia - Goiás. Of the 1096 surgical procedures, 38 of them were to treat CME. Results: was an average age of $59,4 \pm 13$ years, $77 \%$ male and $23 \%$ female, physiotherapeutic care was part of the postoperative routine in $68 \%$ of the cases with no record of its occurrence in the preoperative stages. Conclusion: Physiotherapy was used only in the postoperative stage. Despite the importance of Physiotherapy in the treatment of $\mathrm{CME}$, the studies pertaining to its use in this context are scarce. As a result, more research is necessary to emphasize that its use from the moment of hospitalization could increase the possibilities of surgical recovery.

Keywords: Chagasic Megaesophagus, physiotherapy, Chagas disease. 


\section{INTRODUCTION}

Chagas Disease (CD) occurs through infection by the Trypanossoma cruzi protozoa and, despite vector control, still affects a significant amount of the population. In Latin America, according to the World Health Organization, about 8 million people are infected with a predominance of chronic cases in individuals between 50 and 70 years of age, from endemic regions such as Goiás, Bahia and Minas Gerais in Brazil ${ }^{1-3}$.

The parasite has the ability to survive and reproduce in infected tissue, especially in target organs such as the heart, esophagus and large intestine. Gastrointestinal involvement includes morphologic and functional alterations in the esophagus and large intestine, called Chagasic Megaesophagus (CME) and Chagasic Megacolon (CMC). There is a larger prevalence of CME due to greater vascular support in the myenteric plexus, in the esophagus, in comparison to the large intestine ${ }^{4,5}$.

CME is characterized by luminal enlargement alongside muscular hypotrophy and inflammatory processes in nervous and muscular layers, with a loss of Cajal cells responsible for the organ's peristalsis. Some symptoms of CME include: dysphagia, regurgitation, vomiting, retrosternal pain, odynophagia, night coughs, ptyalism and multiple compensatory swallowing. Due to dysphagia, food can be sucked into the airways, causing repeated pneumonias ${ }^{1,6,7}$.

According to Rezende et al. ${ }^{8}$, CME is classified in stages, in agreement with radiological examination: Stage $I$ is characterized by larger than normal esophagus caliber, contrast retention and slow flow. Stage II is presented as a small to moderate esophagus caliber, contrast retention and tertiary peristaltic waves which can be associated, or not, to esophageal hypotonia. In stage III there is a reasonable increase in organ diameter, reduction in motor activity, hypotonia and large contrast retention. Stage IV is the most advanced of them all - where the esophagus has greater retention capacity, is dilated, atonic and stretched, folding itself over the diaphragm.

There is no definite treatment for $\mathrm{CME}$ since the functional changes are permanent and progressive. Treatment includes a clinical approach, with a change in 
eating habits and medication, and, in more advanced cases or cases presenting greater clinical repercussions, surgery ${ }^{9-11}$.

In the surgery, due to anesthesia and the manipulation of organs near the lungs, it is common the occurrence of pulmonary complications such as atelectasis, tracheobronchitis, pleural effusion, pneumothorax, fistulas in the cervical anastomosis and diminished pulmonary volumes. These complications contribute to longer hospitalization, morbidity and larger death rates in said group ${ }^{12,13}$. Physiotherapy is an area that can be beneficial to CME patients in both pre and postoperative stages due to evidence of its success rate in preventing pulmonary complications - such as pneumonia - as well as the prevention and reversal of pulmonary function, ventilatory muscle strength, global muscle weakness and the reduction of hospitalization time.

The objective of this study was to analyze the use of Physiotherapy during the treatment of the patients that underwent surgical treatment of Chagasic Megaesophagus.

\section{METHODS}

It is a descriptive observational study, done through the analysis of medical records of patients being treated at Goiás Federal University- Hospital das Clínicas. A total of 1096 surgical procedures were analyzed, 38 of them, which had CME, underwent surgical procedures. Patients also had their charts analyzed, filling in a proper evaluation form containing data such as age, sex, origin, CME stage, symptoms, surgery type, associated diseases and lifestyle habits. The research was approved by HC/UFG's Ethics and Research Committee under statute no 777.780.

The data was analyzed first in the Shapiro-Wilk test to evaluate normality. A descriptive statistics was done alongside the Spearman correlation, with a statistical significance $p<0,05$, in order to show the correlation between variables. The analysis was done by the Statistical Package for the Social Science- SPSS version 23. 


\section{RESULTS}

A total of 1096 surgical procedures were done in the analyzed hospital, 38 of which were surgical interventions for CME. It is important to state that this is only a small parcel of CME patients treated at the hospital - since most of them are treated in outpatient care and only cases with greater clinical repercussions and advanced level are referred to surgery. It is possible to observe in our results a higher prevalence of male patients (61\%) with an average age of $59,4 \pm 13$ years as shown in table 1 , below. All patients were from the state of Goiás, $68,4 \%$ of which were from Goiânia and 36,85\% from country towns of Brazil.

Table 1 - Age, sex and origin of patients treated surgically for CME.

\begin{tabular}{ccccccc}
\hline Age (years) & $N$ & $\%$ & Male & Female & Goiânia & $\begin{array}{c}\text { Other cities in } \\
\text { Goiás-Brazil }\end{array}$ \\
\hline $59,4 \pm 13^{*}$ & 38 & 100 & 23 & 15 & & \\
\hline $30-50$ & 9 & 23,7 & 5 & 4 & 5 & 4 \\
$50-70$ & 20 & 52,6 & 13 & 7 & 13 & 7 \\
$>70$ & 9 & 23,7 & 5 & 4 & 6 & 3 \\
\hline Total & 38 & 100 & $23(61 \%)$ & $15(39 \%)$ & $24(68,4 \%)$ & $14(36,85 \%)$ \\
\hline
\end{tabular}

*Mean and Standard Deviation.

The stages of CME that were found, according to the Rezende scale (1989), are as follows: Stage II - 8 patients (21,1\%); Stage III - $17(44,7 \%)$ and $13(34,2)$ patients with stage IV. No correlations were found between stage and age $(p=0,911)$ or stage and gender $(p=0,636)$. The table 2 shows the relation between data: CME stage, age and gender. 
Table 2 - Stages of CME according to sex and age of the sample

\begin{tabular}{lccccc}
\hline \multirow{2}{*}{ Variables } & \multicolumn{3}{c}{ Stage } & Total & p-value \\
\cline { 2 - 4 } & II & III & IV & & \\
\hline Age (years) & & & & & \\
$30-50$ & 3 & 2 & 4 & $9(23,7 \%)$ & \\
$50-70$ & 4 & 9 & 7 & $20(52,6 \%)$ & $0,091^{1}$ \\
$>70$ & 1 & 6 & 2 & $9(23,7 \%)$ & \\
\hline Sex & 3 & 8 & 9 & $15(39 \%)$ & $0,0636^{2}$ \\
Female & 5 & 9 & 9 & $23(61 \%)$ & \\
Male & $8(21,1 \%)$ & $17(44,71 \%)$ & $13(34,2 \%)$ & $38(100 \%)$ & \\
\hline Total & & & & & \\
\hline
\end{tabular}

Caption: ${ }^{1}$ Spearman Correlation (Stage x Age); ${ }^{2}$ Spearman ]correlation (Stage $\mathrm{x}$ Sex).

Patients showed some signs and symptoms such as: dysphagia (100\%), weight loss $(50 \%)$, regurgitation $(44,7 \%)$, vomiting $(21,1 \%)$, heartburn $(15,8 \%)$, odynophagia $(13,2 \%)$ and retrosternal pain $(7,9 \%)$. Dysphagia, present in $100 \%$ of the cases and lasting an average of 10 years, was the main reason for seeking medical and surgical care.

Heller Pinotti $(78,9 \%)$, was the surgical procedure most performed, followed by Serra Dória (13,2\%) and Esophagectomy (7,9\%). The Heller Pinotti procedure was used in less advanced stages wheras Serra Dória and Esophagectomy were used in more advanced stages, with a significant value of $p=0,006$.

Eight patients (21\%) developed postoperative complications: one with a fistula in the cervical anastomosis (2,6\%); three patients developed incisional hernias $(7,9 \%)$; one with pleural effusion (2,6\%); one with pneumonia (2,6\%); one with pulmonary sepsis $(2,6 \%)$; and one with cardiogenic shock $(2,6 \%)$, resulting in the patient's death. The diseases associated to $\mathrm{CME}$, found in the sample were: Arterial Hypertension ( $\mathrm{AH})$, Gastritis, Heart Conditions, Megacolon (CMC), Dyslipedemia, Chronic Obstructive Pulmonary Disease (COPD) and Recurrent Pneumonias. In the sample, $89,5 \%$ considered themselves to have sedentary lifestyles, $23,7 \%$ were smokers and $28,9 \%$ ex-smokers. 
Physiotherapeutic care was part of the postoperative routine in $68 \%$ of the cases with no record of its occurrence in the preoperative stages. The average hospitalization period was of $6,28 \pm 6,8$ days, to hospital discharge, with no influence of Physiotherapeutic care on that period.

Table 3 - Surgical interventions on CME patients and postoperatory Physiotherapeutic care.

\begin{tabular}{lccc}
\hline \multirow{2}{*}{ Surgical Intervention } & \multicolumn{2}{c}{ Physiotherapy } & \multirow{2}{*}{ Total } \\
\cline { 2 - 3 } & No & Yes & \\
\hline Heller Pinotti & 11 & 19 & 30 \\
Serra Dória & 1 & 4 & 5 \\
Esofagectomia & 0 & 3 & 3 \\
\hline Total & $12(31.5 \%)$ & $26(68.4 \%)$ & $38(100 \%)$ \\
\hline
\end{tabular}

\section{DISCUSSION}

The profile of CME patients that were treated surgically throughout the year of the survey was of individuals in the 5 th to 7 th decades of their lives with a prevalence of the male gender. Although some studies show the prevalence of the disease in female individuals ${ }^{14-16}$ Souza et al. ${ }^{17}$ say there is no consensus between CME and gender. Regarding age, our survey average was similar to Santos ${ }^{7}$ study and lower than other studies done with chagasic patients, which had an average age higher than 65 years ${ }^{1,16}$. However, our study had a higher predominance of individuals between $50-70$ years of age. Nevertheless, literature reports a variation in age between 22 and 89 years ${ }^{18}$.

Regarding origin, all individuals operated during the survey were from Goiás, with the majority from Goiânia and a smaller amount from cities in the inland. The region of Goiás- Brazil is classified as endemic for CD7 which probably explains the high extent of the disease. There is also evidence that a large amount of chagasic patients were born in rural areas, having lived in wattle houses and coming in contact with the vector of the disease, the kissing bug or Triatominae ${ }^{16}$.

Regarding the stage of CME, many patients had advanced stages (III and IV), however a study at the same university hospital showed a prevalence of patients with stages I and II of $\mathrm{CME}^{7}$. The studied sample was composed of patients submitted to 
surgical intervention, which is indicated in more advanced cases of the disease. Patients with lower levels were treated clinically.

Regarding possible complications due to surgery, some reports say that the greater the esophageal dilation greater are the chances of postoperative complications $^{19}$, however, the studied sample had lower complication rates. The most frequently used surgical technique in the study was the Heller Pinotti, followed by Serra Dória and Esophagectomy. Heller Pinotti was used for least advanced cases and Serra Dória, along with Esophagectomy was used in more advanced cases. The Heller Pinotti procedure, which is used as a surgical procedure for non-advanced megaesophagus, provides benefits related to dysphagia, regurgitation relief, weight gain and better quality of life, wheras, for more advanced cases or stage IV, the procedures of choice are Serra Dória and Esophagectomy. There is however no consensus on which procedure is best ${ }^{20,21}$.

The main symptoms related to the disease were: dysphagia, weight loss, regurgitation, vomiting, heartburn, odynophagia and retrosternal pain. Dysphagia present in the whole sample and lasting an average of 10 years - is reported in literature as a frequently reported symptom in CME patients, taking up to 9,47 years for patients to seek treatment ${ }^{17,22}$. Kamiji and Oliveira1 verified the presence of dysphagia in all patients equally despite the procedure of choice, not being eliminated with surgery, making new surgeries necessary. In this manner, dysphagia becomes an important problem in these patient's lives, causing great repercussions in their social life as well as life quality.

The main diseases associated to CME found were: arterial hypertension, gastritis, heart disease, CMC, dyslipidemia, Chronic Obstructive Pulmonary Disease and recurrent pneumonias. Reports show a high rate of cardiovascular diseases in chagasic patients with $\mathrm{CME}$ - in which arterial hypertension is more present and indicated as a risk factor to developing chagastic cardiopathy as well as worst cases of cardiopathies ${ }^{1}$ 23-25. However, Gurgel et al. ${ }^{26}$ and Gurgel and Almeida's ${ }^{27}$ studies have shown that patients with $C D$ show the same proportion of arterial hypertension as non-chagasic patients. 
The association between $\mathrm{CME}$ and $\mathrm{CMC}$, literature shows a relation of $15 \%$ to $18 \%$ in occurrences ${ }^{1,22}$ - a lower relation than that observed in our study, where $26,3 \%$ of the sample had CMC. As for the other pathologies, literature does not show any direct relation between their occurrences and $\mathrm{CME}$; however, life habits and the population's prior history can be factors that contribute to the disease's advancement. The sample had a high prevalence of sedentary individuals but there is no evidence as to its relation with CME.

When it comes to postoperative complications, few patients developed complications. Studies have shown that, regarding postoperative complications, the most frequent complication was cervical anastomosis ${ }^{20}$. Dysphagia patients are more prone to malnutrition, which is shown in literature as the main cause for a higher average hospitalization time as well as an increase in postoperative complications 28. Extended stays in intensive care units - longer than seven days - have been shown to have direct association with the development of said complications.

Various risk factors can favor the development of postoperative complications, such as age, sex, associated diseases, dysphagia level, nutritional status, surgery time and previous pulmonary diseases30. Pulmonary complications are villains in the recovery of patients submitted to surgical procedures and can cause an increase in hospitalization time ${ }^{29}$.

Respiratory Physiotherapy has been gaining ground and has been used in the pre and postoperative stages of various surgeries; there is also evidence that shows its success in the prevention of pulmonary complications in corrective surgeries for $\mathrm{CME}^{30}$.

Physiotherapeutic care was part of the postoperative clinical routine of little over half of the cases, with no record of its use in preoperative stages. The average hospitalization time was of 6 days until their discharge, with no influence of Physiotherapy in the time span. Although the patients in the sample did not have Physiotherapy treatment in the preoperative stages, its benefits - from a patients hospitalization to his discharge - are well known and useful in preventing postoperative pneumonias, which reduces pulmonary complications, enabling the maintenance of both pulmonary and motor function. 
Despite the importance of Physiotherapy in the treatment of CME, the studies pertaining to its use in this context are scarce. As a result, more research is necessary to emphasize that its use from the moment of hospitalization could increase the possibilities of surgical recovery.

\section{REFERENCES}

1. Kamiji MM, Oliveira RB. O perfil dos portadores de doença de Chagas, com ênfase na forma digestiva, em hospital terciário de Ribeirão Preto- SP. Rev. Soc. Bras. Med. Trop. 2005; 38: 305-09.

2. ORGANIZAÇÃO PAN AMERICANA DA SAÚDE. Guia para vigilância, prevenção, controle e manejo clínico da doença de Chagas aguda transmitida por alimentos. Rio de Janeiro: PANAFTOSA-VP/OPAS/OMS; p. 92. (Serie de Manuais Técnicos, 12), 2009.

3. WORLD HEALTH ORGANIZATION. Chagas disease (American trypanosomiasis); 2015 [Acesso em 16 de fevereiro de 2015]. Disponível em: http://www.who.int/mediacentre/factsheets/fs340/en/.

4. Adad SJ, Etchebehere RM, Jammal AA. Blood vessels in ganglia in human esophagus might explain the higher frequency of megaesophagus compared with megacolon. Rev. Soc. Bras. Med. Trop.2014; 56: 529-532.

5. Marcon GEB, Albuquerque DM, Batista AM, Andrade PD, Almeida EA, Guariento ME, et al. Trypanosoma cruzi: parasite persistence in tissues in chronic chagasic Brazilian patients. Mem. Inst. Oswaldo Cruz 2011; 106: 85-91.

6. Pinazo MJ, Cãnas E, Elizalde JI, García M, Gascón J, Gimeno F, et al. Diagnosis, management and treatment of chronic Chagas gastrointestinal disease in areas where Trypanosoma cruzi infection is not endemic. Gastroenterol. Hepatol. 2010;33:191- 200.

7. Santos CMD, Cassiani RDA, Dantas RO. Avaliação clínica da deglutição na doença de Chagas; Clinical evaluation of swallowing in Chagas disease. Rev. Soc. Bras. Fonoaudiol. 2011; 16; 215-20.

8. Rezende JM. Classificação radiológica do megaesôfago. Rev. goiana med. 1982; 28(3/4): 187-91.

9. Costantini N, Zaninotto G, Guirroli E, Rizzetto Z, Portale G, Ruol A, et al. The laparoscopic Heller-Dor operation remains na effective treatment for esophageal achalasia at a minimum 6-year follow-up. Surg. Endosc. 2005; 19: 345-351. 
10. Loviscek MF, Wright AS, Hinojosa MW, Petersen R, Pajitnov D, Oelschlager BK, et al. Recurrent dysphagia after Heller Miotomy: Is esophagectomy Always the answer? FACS 2013; 216: 736-743.

11. Oliveira GC, Lopes LR, Andreollo NA, Braga NS, Coelho Neto JS. Tratamento cirúrgico do megaesôfago no Hospital de Clínicas da UNICAMP-fatores associados a melhores ou a piores resultados. Rev. Col. Bras. Cir. 2009; 36: 300-306.

12. Assunção-Neto A, Eichler KS, Soares LMS, Veronezi RJB, Silva A. Fatores de risco para complicações pulmonares no pós-operatório de cirurgia de megaesôfago: uma visão fisioterapêutica. Rev. cienc. med. 2008; 17: 185-191.

13. Bellinetti LM, Thomson JC. Avaliação muscular respiratória nas toracotomias e laparotomias superiores eletivas. J. bras. Pneumol. 2006; 32: 99-105.

14. Alves RA. Autopercepção da saúde, co-morbidades e uso de medicamentos em idosos chagásicos, acompanhados no grupo de estudos em doenças de chagas GEDOCH - UNICAMP. Dissertação [Mestrado em Gerontologia], Campinas, Faculdade de Ciências Médicas, Universidade de Campinas, 2008, 145p.

15. Castro C, Prata A, Macêdo V. Estudo clínico durante 13 anos de 190 chagásicos crônicos de Mambaí, Goiás, Brasil. Rev. Soc. Bras. Med. Trop. 2001; 34: 309-318.

16. Alves RMA, Thomaz RP, Almeida EA, Wnaderley JS, Guariento ME. Chagas' disease and ageing: the coexistence of other chronic diseases with Chagas' disease in elderly patients. Rev. Soc. Bras. Med. Trop.2009; 42: 622-628.

17. Souza AC, Rocha MOC, Teixeira AL, Júnior JOD, Sousa LAP, Nunes MCP. Depressive symptoms and disability in chagasic stroke patients: Impact on functionality and quality of life. J. neurol. Sci 2013; 324: 34-37.

18. Bozelli CE, Araújo SM, Guilherme ALF, Gomes LF. Perfil clínico-epidemiológico de pacientes com doença de Chagas no Hospital Universitário de Maringá, Paraná, Brasil. Cad. Saúde Pública 2006; 22: 1027-1034.

19. Garcia Neto J. Avaliação do risco cirúrgico no paciente portador de megaesôfago chagásico e sua relação com o grau de dilatação. Dissertação [Mestrado em Ciências], São Paulo, Faculdade de Medicina da Universidade de São Paulo, $2003,145 p$.

20. Oliveira GC, Rocha RLB, Coelho Neto JS, Terciotti-Junior V, Lopes LR, Andreollo NA. Mucosectomia esofágica versus esofagectomia: Estudo comparativo dos resultados cirúrgicos imediatos e tardios em pacientes operados por megaesôfago avançado. ABCD Arq Bras Cir Dig 2015; 28:28-31.

21. Alves L, Zilberstein B, Trevenzol HP, Penhavel FAZ, Neder J. Operação de Serra-Dória no tratamento do megaesôfago chagásico avançado: resultados imediatos. Arq Bras Cir Dig 2003; 16: 120-123. 
22. Oliveira GC, Lopes LR, Andreollo NA, Coelho Neto JS. O megaesôfago tratado cirurgicamente: perfil epidemiológico dos pacientes operados no Hospital de Clínicas da Universidade Estadual de Campinas entre 1989 e 2005. Rev. Soc. Bras. Med. Trop. 2008; 41: 183-88.

23. Guariento ME, Alliegro FC, Almeida EA. Doença de Chagas associada a doenças crônicas em pacientes assistidos em ambulatório de hospital universitário. Rev. Soc. Bras. Clín. Méd. 2009; 7: 84-88.

24. Pereira LS. Perfil clínico e epidemiológico de pacientes idosos com doença de chagas atendidos no serviço de atenção farmacêutica, entre 2005 a 2013. Dissertação [Mestrado em Patologia], Fortaleza, Faculdade de Medicina, Universidade Federal do Ceará, 2014, 95p.

25. Almeida $E A$, Neto RMB, Guariento ME, Wanderley ME, Souza ML. Apresentação clínica da doença de Chagas crônica em indivíduos idosos. Rev. Soc. Bras. Med. Trop. 2007; 40: 311-315.

26. Gurgel CBFM, Almeida EA. Frequência da hipertensão Arterial em Chagásicos Crônicos e sua repercussão no Coração: Estudo Clínico e Anatomopatológico. Arq Bras Cardiol 2007; 89: 191-200.

27. Oliveira LB, Rocha Junior PB, Guimarães NM, Didonet MT. Variáveis relacionadas ao tempo de internação e complicações no pós-operatório de pacientes submetidos à cirurgia do trato gastrointestinal. Com. Ciências Saúde 2010; 21: 319-330.

28. Gagliardi D, Corsi PR, Frimm CE, Fava J. Câncer de esôfago: complicações e letalidade hospitalar. Rev Col Bras Cirur. 2004; 31(1):2-9.

29. Law S, Wong KM, Kwok KF, Chu KM, Wong J. Predictive factors for postoperative pulmonary complications and mortality after esophagectomy for cancer. Ann Surg. 2004; 240(5):791-800.

30. Bellinetti LM, Thomson JC. Avaliação muscular respiratória nas toracotomias e laparotomias superiores eletivas. J Bras Pneumol. 2006; 32(2):99-105. 